\title{
THE EFFECT OF SLOW RELEASING ORAL MAGNESIUM CHLORIDE ON THE QT INTERVAL OF THE ELECTROCARDIOGRAM DURING OPEN HEART SURGERY
}

\author{
Barry S. Krasner, Robert Girdwood and Harry Smith
}

\begin{abstract}
Recent work in both animal and human studies emphasizes the value of magnesium in the maintenance of the functional and structural integrity of cardiac muscle. Both intracellular and extracellular magnesium concentrations can vary independently and the serum and red cell magnesium levels may not give an accurate account of intracellular cardiac magnesium deficiency. However, electrocardiographic studies of magnesium levels could provide an accurate index of intracellular cardiac magnesium levels.

Twenty-four patients scheduled electively for mitral valve replacement were studied to evaluate the effect of slow releasing oral magnesium chloride on the $\mathrm{QT}_{\mathrm{c}}$ interval of the electrocardiogram. Although pretreatment $\mathrm{QT}_{\mathrm{c}}$ values in all patients were not significantly different, there was a highly significant difference between the control group and the treatment group after four days of preoperative treatment with oral magnesium chloride. During the postoperative phase of the trial, all patients developed a similar pattern of increase in $\mathrm{QT}_{\mathrm{c}}$ interval, reaching a peak at the end of the second day and followed by a decrease over the final two days. All patients who developed arrhythmias postoperatively had not been pretreated (primed) with oral magnesium chloride and had abnormal $\mathrm{QT}_{\mathrm{c}}$ intervals both before and after operation.

The results of this study demonstrate the usefulness of oral magnesium chloride in reducing the $\mathrm{QT}_{\mathrm{t}}$ interval of the electrocardiogram and so protecting the myocardium against possible arrhythmias.
\end{abstract}

KEY WORDS: HEART, electrocardiogram, $\mathrm{QT}_{\mathrm{c}}$ interval, magnesium.

RECENT WORK in both animal ${ }^{1-3}$ and human studies ${ }^{4-7}$ emphasizes the value of magnesium in the maintenance of the functional and structural integrity of cardiac muscle. Intracellular and extracellular magnesium concentrations can vary independently and a deficit in one compartment may not be accompanied by a significant change in the other. ${ }^{8}$ The assessment of the serum magnesium is therefore not a true and reliable index of the intracellular magnesium level. Furthermore, the exchange of magnesium ions occurs much more rapidly in heart muscle than in other tissues. ${ }^{9}$

The $\mathrm{QT}_{\mathrm{f}}$ interval of the electrocardiogram represents the total duration of ventricular systole and should not exceed 0.42 seconds in men

Barry S. Krasner, M.D., M.B., Ch.B., F.F.A.R.C.S., Department of Anesthesiology, Lenox Hill Hospital, New York, N.Y. 10021, USA; Robert Girdwood, M.B., B.Ch., F.R.C.S., Cardiothoracic Unit, Baragwanath Hospital, University of Witwatersrand, Johannesburg, South Africa; Harry Smith, Ph.D., Department of Biostatistics, Mount Sinai School of Medicine, New York.

Address for Correspondence: Barry S. Krasner, M.D., Ruppert Towers, 1619-3rd Avenue, Apt. 11J East, New York, N.Y. 10028, U.S.A.

Canad. Anaesth. Soc. J., vol. 28 , no. 4, July 1981 and 0.43 seconds in women. ${ }^{10} \mathrm{~A}$ prolonged $\mathrm{QT}$. interval results from delayed repolarization of the ventricular myocardium. It is during this period that the patient is highly vulnerable to cardiac arrhythmias with myocardial infarction and death. ". It has been predicted that certain individuals with congenitally prolonged $\mathrm{QT}_{\mathrm{c}}$ intervals are at increased risk of fatal ventricular fibrillation when conditions causing hypoxia or sympathetic discharge occur ${ }^{16}$ Based on measurement of the $\mathrm{QT}_{\mathrm{c}}$ intervals and clinical observations during magnesium therapy for anxiety states, ${ }^{11}$ it was decided to study the effects of slow releasing oral magnesium chloride on the electrocardiogram during cardiopulmonary bypass procedures.

\section{METHODS}

Twenty-four patients ranging in age from 14 to 58 years scheduled electively for mitral valve replacement utilizing cardiopulmonary bypass were selected to participate in the study. All patients had been using some type of diuretic agent and had been digitalized for at least two months before operation. All patients had not 
been taking magnesium-containing drugs for the same period of time. It was not necessary to administer diuretics or to digitialize any of the patients during the immediate preoperative period. Informed consent and institutional approval were obtained for all patients participating in the investigation. Upon hospitalization baseline electrocardiographic studies and a full blood count were done, and serum electrolytes were determined on all 24 patients. The rate and rhythm of all preoperative electrocardiographic tracings were normal. The average preoperative $\mathrm{QT}_{\mathrm{c}}$ interval of the electrocardiogram for all patients was 0.425 seconds with a standard deviation of 0.025 seconds. The patients were then randomly assigned to one of two treatment arms: Group I (treatment): patients who received oral magnesium tablets for four days preoperatively. Each tablet contained $535 \mathrm{mg} \mathrm{MgCl} \cdot 6 \mathrm{H}_{2} \mathrm{O}$. The oral dosage was $80 \mathrm{mg}$ per kilogram body weight. Group II (control): patients who received oral placebo tablets identical in size, shape, and colour to the magnesium chloride tables. The tablets were administered to the patients from coded bottles by the nursing staff and at the beginning of the fifth day, open heart surgery was done. All patients were premedicated using morphine $0.1 \mathrm{mg} \cdot \mathrm{kg}^{-1}$ and atropine $0.05 \mathrm{mg} \cdot \mathrm{kg}^{-1}$. Anaesthesia was induced using thiopentone sodium and neuromuscular blockade attained using succinylcholine $1.5 \mathrm{mg} \cdot \mathrm{kg}^{-1}$. Following tracheal intubation ventilation was controlled to maintain $\mathrm{Pa}_{\mathrm{CO}_{2}}$ of $4.66-5.32 \mathrm{kPa}$ (35-40 torr). Anaesthesia was maintained with a mixture of nitrous oxide and oxygen (50:50), pancuronium $0.1 \mathrm{mg} \cdot \mathrm{kg}^{-1}$ and morphine sulphate $0.15 \mathrm{mg} \cdot \mathrm{kg}^{-1}$ increments intravenously.

During cardiopulmonary bypass the composition of the pump priming solution was two units of fresh blood and one unit of plasmalyte $B$ $(1000 \mathrm{ml})$. Plasmalyte $B$ is a balanced solution of electrolytes containing sodium $130 \mathrm{mmol}$ per litre, potassium $4 \mathrm{mmol}$ per litre, bicarbonate $28 \mathrm{mmol}$ per litre, and the pH of solution is 7.4 . The exact composition of cardioplegic solution was the same in all cases and consisted of $1000 \mathrm{ml}$ of plasmalyte B to which was added $30 \mathrm{mmol}$ potassium, $16 \mathrm{ml} 50$ per cent dextrose, $2.5 \mathrm{ml}$ sodium bicarbonate $8.4 \%$ solution, $1.0 \mathrm{ml}$ calcium chloride $10 \%$ solution, $500 \mathrm{mg}$ solumedrol. The osmolarity of the solution was approximately 330 and the $\mathrm{pH}$ was 7.38 . All patients were cooled to $28^{\circ} \mathrm{C}$ during bypass.

Immediately after operation electrocardiographic studies were made and the $\mathrm{QT}_{\mathrm{c}}$ intervals were measured for four consecutive postoperative days. Any arrhythmias that occurred during the postoperative phases were also noted and recorded.

Groups I and II were compared for the average per patient change in $\mathrm{QT}_{\mathrm{c}}$ interval from initial admission to the time just before the operation four days later, using a paired t-test. The comparison of postoperative $\mathrm{QT}_{\mathrm{c}}$ interval changes was done using repeated measure analysis of variance techniques. Finally, if enough arrhythmias occurred during the trial, a comparison of this subgroup of patients with the arrhythmia-free group of patients was made.

\section{Results}

After the allocation of patients to Group I (treatment) and Group II (control) was made, average pretreatment $\mathrm{QT}_{\mathrm{c}}$ intervals \pm one standard deviation were: Group I: $0.428 \pm 0.026$ and Group II: $0.422 \pm 0.024$. These were not significantly different.

At the end of the four day preoperative treatment, those patients on oral magnesium chloride had an average decrease in $Q T_{c}$ interval of 0.0279 seconds. The untreated control patients had an average increase in $\mathrm{QT}_{\mathrm{c}}$ interval of +0.0076 seconds. This difference in the average change was statistically significant $(t=7.15 \mathrm{p}<0.001)$. (Figure 1).

During the postoperative phase of the trial, all patients had a similar pattern of a rise in the $\mathrm{QT}_{\mathrm{c}}$ interval during the first two postoperative days, followed by a decrease in the last two days of observation. This pattern is shown in Figure 1, and can be represented mathematically by a quadratic function. Using least squares a quadratic equation was fitted to both the treated groups and to the control group. A plot of the two fitted equations shows them parallel, with the distance between them indicating the effect of oral magnesium chloride priming on the $\mathrm{QT}_{\mathrm{c}}$ interval. This difference was 0.0293 seconds $\mathrm{QT}_{\boldsymbol{c}}$ interval less for the treated group during the four postoperative days. This was statistically significant ( $\mathrm{p}<$ 0.01 ).

Figure 2 shows the patterns in $\mathrm{QT}_{\mathrm{c}}$ intervals for the two control groups and the treated group. Again, the patterns are almost identical and the same general quadratic function described previously holds here as well. Thus, once the preoperative $\mathrm{QT}_{\mathrm{c}}$ level has been established, the $\mathrm{QT}_{\mathbf{c}}$ response curves for the three groups are 


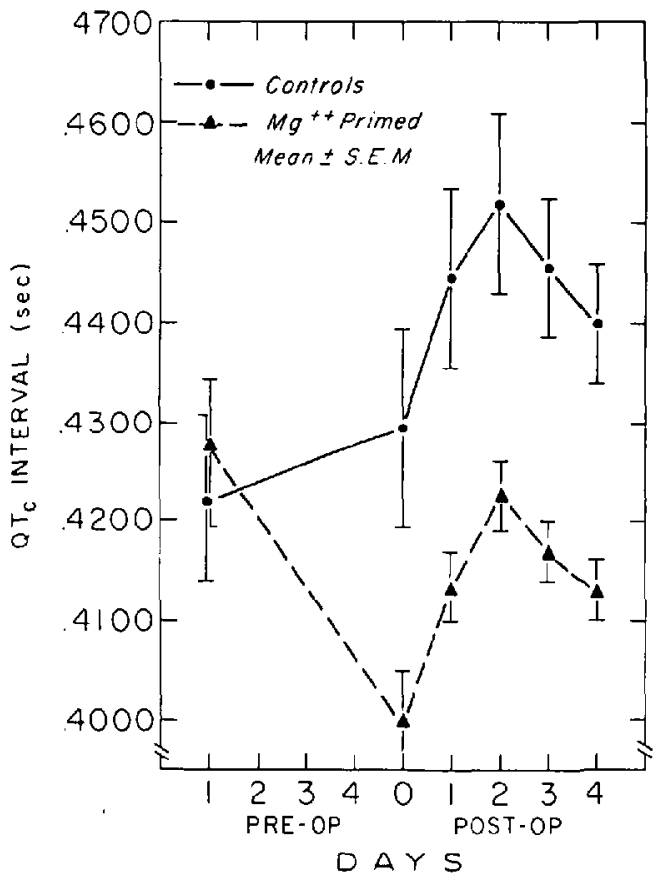

Figure I Comparison of $\mathrm{QT}_{\mathbf{c}}$ intervals in control and treated groups.

- controls.

$\Delta=\mathrm{Mg}^{++}$primed.

quadratic and parallel. Using repeated measures ANOVA, the $F$ for parallelism was $F(4,12)=$ 0.76 (N.S.).

Five patients developed arrhythmias postoperatively. Three developed ventricular extrasystoles, one a bigeminal rhythm and one paroxysmal atrial tachycardia. All five of these patients were on the control arm of the trial. Retrospectively, a re-analysis of the data was done by dividing Group II (control) into two groups, controls with dysrhythmias and controls without dysrhythmias. Table I shows the preoperative changes in $\mathrm{QT}_{c}$ intervals for all three groups (the two control groups and the treated groups). While the change in $\mathrm{QT}_{c}$ interval was larger for those in the control who developed DYS; i.e. + 0.0132, compared to those in the control who did not develop DYS; i.e. $=0.0036$, statistically they were not significantly different $(\mathrm{t}=1.38, \mathrm{p}>0.15)$.

\section{Discussion}

Magnesium is involved in normal mitochondrial contraction with the formation of the magnesium-ATP complex which is the true substrate

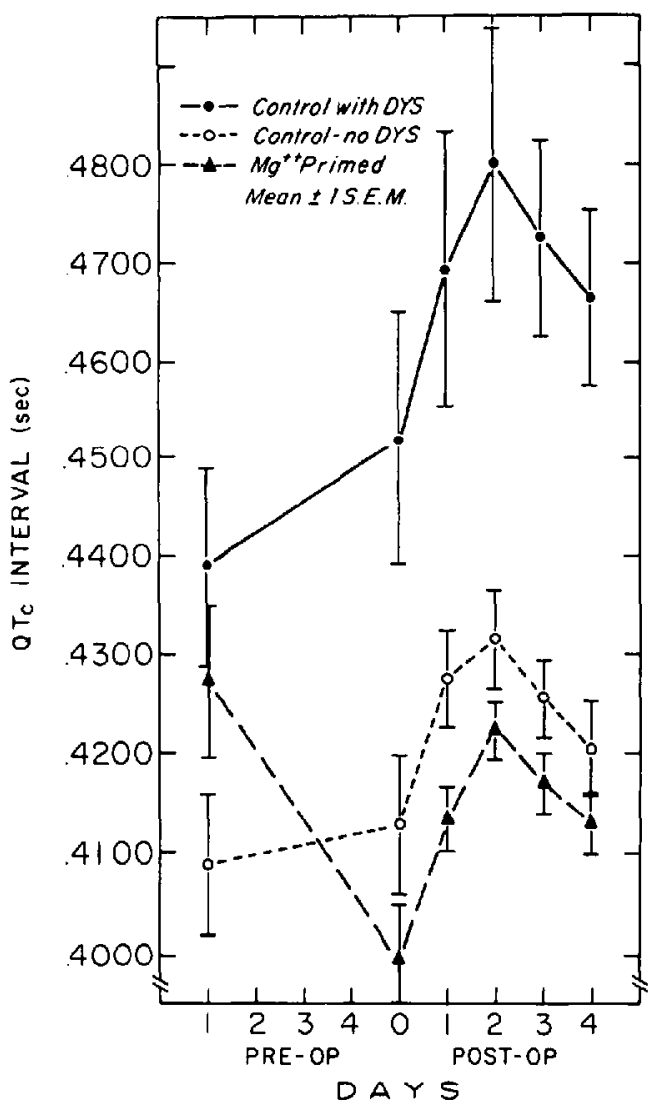

FIGURE 2 Comparison of $\mathrm{QT}_{\mathrm{c}}$ intervals in controls with dysrhythmias, controls with no dysrhythmias and treated group.

- = control with dysrhythmias.

$\mathrm{O}=$ control with no dysrhythmias.

$\Delta=\mathrm{Mg}^{++}$primed.

for all reactions involving ATP14. Magnesium also affects the sodium-potassium ATPase of heart membranes, and activates adenyl cyclase in heart muscle. ${ }^{15}$ With depletion of cardiac magnesium as a result of ischaemia, anoxia or the administration of cardiotoxic drugs, ATPase becomes inactivated and oxidative phosphorylation is inhibited. Cellular potassium effux and sodium influx takes place and mitochondrial swelling occurs, ultimately resulting in myocardial fibre necrosis. ${ }^{1-13}$ Magnesium is thus vital in the maintenance of mitochondrial integrity and in the retention of myocardial potassium. Several factors may contribute to the postoperative fall in magnesium levels and the development of arrhythmias in patients undergoing open heart surgery using cardiopulmonary bypass. These include a preoperative magnesium deficiency in 
TABLE I

$\mathrm{QT}_{\mathrm{c}}$ Interval Changes Preoperatively (Mean \pm S.E.M.)

\begin{tabular}{lccc}
\hline \hline \multicolumn{1}{c}{ Group } & $\begin{array}{c}\text { Pre-Mg } \\
\text { Level }\end{array}$ & $\begin{array}{c}\text { Post-Mg } \\
\text { Pre-op } \\
\text { Level }\end{array}$ & $\begin{array}{c}\text { Average } \\
\text { Change }\end{array}$ \\
\hline Control with DYS $(\mathrm{n}=5)$ & $0.4390 \pm 0.0098$ & $0.4522 \pm 0.0127$ & $+0.0132 \pm 0.0036$ \\
Control without DYS $(n=7)$ & $0.4090 \pm 0.0068$ & $0.4126 \pm 0.0069$ & $+0.0036 \pm 0.0008$ \\
Treated (Primed) with $\mathrm{Mg}(\mathrm{n}=12)$ & $0.4275 \pm 0.0076$ & $0.3996 \pm 0.0047$ & $-0.0279 \pm 0.0045$ \\
\hline
\end{tabular}

DYS = dysrhythmia.

patients with cardiac pathology, anaesthesia using artificial ventilation with hyperventilation, haemodilution, acid-base disturbances, duration of perfusion, and the use of drugs. The careful monitoring of intracellular magnesium levels is thus of prime importance. The serum and red cell magnesium levels may not be an accurate reflection of intracellular cardiac magnesium deficiency. However, electrocardiographic studies could provide an accurate index of intracellular cardiac magnesium levels and can be a valuable way of detecting changes in the electrophysiological events in the myocardium during magnesium deficiency and magnesium therapy.

The effect of an enteric-coated slow releasing oral tablet of magnesium chloride on the $\mathrm{QT}_{\mathrm{c}}$ interval during open heart surgery was interesting statistically. Although pretreatment $\mathrm{QT}_{\mathrm{c}}$ values were not significantly different, there was a highly significant difference between the treatment and control groups following four days of oral magnesium chloride treatment in the preoperative period. It was also very interesting to note that during the postoperative phase of the trial, all patients developed a similar pattern of a rise in the $\mathrm{QT}_{\mathrm{c}}$ interval, reaching a peak at the end of the second day, followed by a decrease over the next two days. Finally, it should be noted that all five patients who developed arrhythmias postoperatively had not been pretreated (primed) with oral magnesium chloride and that those patients had an abnormal $\mathrm{QT}_{\mathbf{c}}$ interval both before and after operation.

The results of this study demonstrate the use of oral magnesium chloride in reducing the $\mathrm{QT}_{\mathrm{c}}$ interval of the electrocardiogram and so protecting the myocardium against possible arrhythmias. The potential of prophylactic use of oral magnesium in heart disease is illustrated.

\section{ACKNOWLEDGEMENTS}

The authors wish to thank Mr. A.L. Warren,
Director of Glenfair Pharmaceuticals, Pretoria, South Africa who supplied the oral magnesium tables (slow releasing) U.S. Patent No. 4,150111, and Dr. W.H. Davis, for continued advice during the project.

\section{REFERENCES}

1. Lehr, D., Chau, R. \& Irene, S. Possible role of magnesium loss in the pathogenesis of myocardial fiber necrosis. Recent Advan. Stud. Cardiac Struct. Metabol. 6: 95 (1975).

2. Fedelesova, M., et al. Prevention by $\mathrm{K}^{+}$, $\mathrm{MG}^{++}$-Asparate of isoproterenol-induced metabolic changes in the myocardium. Recent Advan. Stud. Cardiac Struct. Metabol. 6: 59 (1975).

3. SEELIG, M.S. Myocardial loss of functional magnesium in cardiomyopathies of diverse etiology. Recent Advan. Stud. Cardiac Struct. Metabol. 1: 626 (1972).

4. Chipperfield, B. \& Chipperfield, J.R. Heartmuscle magnesium, potassium and zinc concentrations after sudden death from heart-disease, Lancet 2: 293 (1973).

5. BEhr, G. \& BurTON, P. Heart-muscle magnesium Lancet 2: 450 (1973).

6. Chipperfield, B., Chipperfield, J.R., Behr, G., et al. Lancet 1: 21 (1975).

7. Krasner, B.S. \& Girdwood, R. The use of oral magnesium chloride (slow releasing) in open-heart surgery with special reference to arrhythmias and recovery times. Abstracts of Scientific Papers, A.S.A. Meeting, Chicago, 589-590 (1978).

8. WALLACH, S. \& DimiCH, A. Radiomagnesium turnover studies in hypomagnesemic states. Ann. N.Y. Acad. Sci. 162: 963-972 (1969).

9. AIKAWA, J.K. The role of magnesium in biologic processes, Springfield, Ill. Charles C. Thomas (1963).

10. Lipman, B.G., Massie, E. \& Kleiger, R.E. Clinical scalar electrocardiography. Year Book Medical Publishers, p. 570, (1972).

11. KRASNer, Barry $S$. Cardiac effects of magnesium with special references to anaesthesia: a review. Canad. Anaesth. Soc. J. 26: 181-185 (1979).

12. LABORIT, H. New physiological concepts of cardiovascular functions. Therapeutic consequences. In: Electrolytes and Cardiovascular Diseases, edited by E. Bajusz, Basel: Karger, vol. 2, p. 239 (1966).

13. NiePER, H.A. \& Blumberger, K. Electrolyte 
transport therapy of cardiovascular diseases. In: Electrolytes and Cardiovascular Diseases, edited by E. Bajusz, Basel: Karger, vol. 2, p. 141 (1966).

14. SzEnT-GYoRgYi, A. The ATP molecule, bioenergetics, New York, Academic Press, Inc., p. 64 (1957).

15. Polimeri, P. I. \& Page, E. Magnesium in heart muscle, Circ. Res. 33: 367 (1973).
16. Schamroth, L. An introductory to electrocardiography. 3rd ed., Blackwell Scientific Publications, p. 175 (1966).

17. Schwartz, P.J. Cardiac sympathetic innervations and the sudden infant death syndrome. Am. J. Med. 60: 176-172(1976).

\section{RÉSUMÉ}

Des études récentes effectuées chez l'homme et chez l'animal ont souligné le rôle important du magnésium dans le maintien de l'intégrité structurelle et fonctionnelle du muscle cardiaque. Comme les concentrations intra et extra-cellulaires du magnésium peuvent varier de façon indépendante, les déterminations dex taux de magnésium dans les globules rouges et dans le sérum peuvent ne pas révéler des déficiences de cet ion dans la cellule myocardique. L'étude des modifications électrocardiographiques pourrait d'autre part fournir un index précis de la concentration de cet ion au niveau de la cellule myocardique.

Vingt quatre patients devant subir un remplacement valvulaire mitral ont fait l'objet d'une étude dont le but était d'évaluer l'influence d'une administration orale de chlorure de magnésium à libération lente sur la durée de l'intervalle $\mathrm{QT}_{c}$ de l'électrocardiogramme. Une différence hautement significative a été observée dans la durée de l'intervalle $\mathrm{QT}_{\mathrm{c}}$ des malades ainsi traités au chlorure de magnésium pendant quatre jours avant la chirurgie par rapport à celle trouvée chez les patients non traités. Après l'intervention, la durée de l'intervalle $Q \mathrm{~T}_{c}$ s'est prolongée chez tous les patients, le maximum de prolongation survenant au deuxième jour post-opératoire pour ensuite se raccourcir durant les deux jours suivants. Tous les cas d'arythmie observés sont survenus chez des patients n'ayant pas reçu de chlorure de magnésium avant l'intervention et les intervalles ${ } T_{c}$ de tous ces patients étaient anormaux avant et après la chirurgie.

Les résultats de ce travail démontrent que l'administration de chlorure de magnésium se traduit au niveau de l'électrocardiogramme par un raccourcissement de l'intervalle $Q T_{c}$ et contribue à prévenir des arythmies éventuelles. 